\title{
DELAYED RESULTS OF TREATMENT OF PARACOCCIDIOIDOMYCOSIS WITH AMPHOTERICIN B PLUS SULFAMIDES VERSUS AMPHOTERICIN B ALONE
}

\author{
Neuza Lima DilloN (1), Sebastiāo A. P. SAMParo (2), Marta Cassoni HabermanN (3), Silvio \\ alencar MARQUES (4), Joel Carlos LASTORIA (5), Hamilton Ometto STOLF (6), Nilson Camargo de \\ Andrade SILVA $(\gamma)$ \& Paulo Roberto CURI (8)
}

\section{S U M M A R Y}

A delayed evaluation of two groups of patients with paracoccidioidomycosis was carried out. Both groups were treated with amphotericin B, but one of them was submitted to maintenance treatment with sulfonamides. Statistical analysis showed that treatment is more effective when patients are maintained with sulfonamide drugs.

KEY WORDS: Human paracoccidioidomycosis - Treatment with amphotericin and sulfamides

\section{N T R O D U G T I O N}

Amphotericin $B$ and the sulfonamides are drugs that have been effectively used in the treatment of paracoccidioidomycosis, either separately or in association.

Many reports have been published both in Brazil and abroad on the therapeutic results 1 , $2.5,7,8,9,10,11,12$ and the side effects $3,4,14$ of these drugs. SAMPAIO 13 and DILION 6 concluded cn the superiority of amphotericin $B$ when compared to separately administered sulfonamides. No studies, however, have been carried out to compare the therapeutic results obtained with amphotericin $B$ alone and associated with sulfonamides for the maintenance treatment of paracoccidioidomycosis, and the present study was undertaken with the objective to make such a comparison.

\section{MATERIAL AND METHODS}

The study was carried out on two groups of patients with paracoccidioidomycosis. The first consisted of 69 patients treated with amphotericin B only at the University Hospital of the Faculty of Medicine of the University of São Paulo from 1958 to 1963 , and studied by SAMPAIO (1960) and DILLON (1972). The second consisted of 42 patients treated with amphotericin B and submitted to maintenance treatment with sulfonamides at the University Hospital of the Faculty of Medicine of Botucatu from 1968 to 1982.

The patients were grouped by phases on the basis of time without treatment. Thus, Pha. se $1=$ less than 1 year; Phase $2=1$ to 2 years; Phase $3=2$ to 5 years; Phase $4=5$ to 9 years; Phase $5=9$ to 14 years. Patients were evaluated

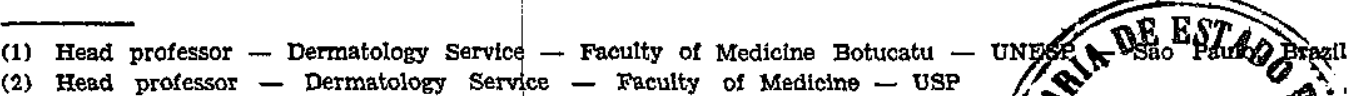

(3) Assistant professor - Dermatology Service - Faculty of Medicine - Botucatak U Y 95

(4) Assistant professor - Dermatology Service - Faculty of Medicine - Botuctal DI

(5) Instructor - Dermatology Service - Faculty of Medicine Botucatu - UNqFE BIBLEORAFIA

(6) Instructor - Dermatology Service - Faculty of Medicine Botucatu - UNE\$P

(7) Resident - 2nd degree - Dermatology Service - Facuity of Medicine - Eotucatu - UNESP

(8) Assistant professor - Department of Surgery Faculty of Medicine - Botucatid - DNESP. 
DILLON, N. L.; SAMPAIO, S. A. P.; HABERMANN, M. C.; MARQUES, S. S.; LASTORIA, J. C.; STOLF, H. O.; SILVA, N C. de A. \& CURI, P. R. - Delayed results of treatment of paracoccidioidomycosis with amphotericin B plus sulfamides versus amphotericin B alone. Rev. Inst. Med. trop. Săo Paulo, 28:263-266, 1986.

on the basis of clinical, radiologic and serologic cata, distributed among the following classes: FCRS = free from clinical, radiologic or serologic lesions $\mathrm{SA}=$ with serologic activity on$\mathrm{ly}$; WCRS = with clinical, radiologic and sero. logic lesions; DWSL $=$ death with specific lesions.

The groups were evaluated for homogeneity in terms of sex, age range, organic involve. ment and number of amphotericin $B$ series by the $\mathrm{X}^{2}$ test ${ }^{16}$. For the last similarity factor, i.e., the total dose of amphotericin $B$ adminis. tered, and for comparison of the treatments, we utilized the KOLMOGOROV-SMIRNOV ${ }^{*}$ test for two independent samples and determined the distribution of the two groups in terms of classes for each phase. In these tests, we consider $\mathrm{F} 6=\mathrm{F} 4+\mathrm{F} 5$ and $\mathrm{X}=0.05$.

To compare treatments at each phase, sco. res were given to each class according to the general condition of each patient: class $1=8$ points; class $2=4$ points; class $3=2$ points; class $4=1$ point. An index was obtained by summing the number of cases in each class multiplied by the respective points. The results were analyzed statistically by binomial test 16 .

\section{RESULTS AND DISCUSSION}

The two groups were homogenous in terms of sex, age range, organic involvement, dose of amphotericin B (number of series and total dose administered), as shown in Tables I, II, III, I Vand V, respectively.

T A B L E I

Patient distribution by sex

\begin{tabular}{lcr}
\hline Sex & Group I & Group II \\
\hline Male & 63 & 39 \\
Female & 6 & 3
\end{tabular}

$\mathrm{x}^{2}=0.08$

T A B I $\mathbf{E}$ II

Patient distribution by age range

\begin{tabular}{lcr}
\hline Age range & Group I & Group II \\
\hline 0 to 20 years & 5 & 4 \\
20 to 40 years & 31 & 12 \\
+40 years & 33 & 26 \\
\hline$X^{*}=1.79$ & &
\end{tabular}

T A B L E III

Patient distribution by organic involveemnt

\begin{tabular}{lrr}
\hline Involvement & Group I & Group II \\
\hline Sinin and mucosa & 10 & 11 \\
Lungs & 2 & 1 \\
Ganglia & 2 & 0 \\
Mixed & 55 & 30 \\
\hline$X^{2}=1.58$ & &
\end{tabular}

T A B I E IV

Patient distribution by the number of amphotericin $B$ series performed

\begin{tabular}{crr}
\hline Series & Group I & Group II \\
\hline 1 & 44 & 29 \\
2 & 12 & 8 \\
3 & 4 & 5 \\
4 & 7 & - \\
5 & 1 & - \\
9 & 1 & - \\
\hline
\end{tabular}

T A B L E V

Patient distribution by total dose in the different amphotericin B series

\begin{tabular}{lcr}
\hline Dose (g) & Group I & Group II \\
\hline $0.5-1$ & 5 & 7 \\
$1-2$ & 24 & 12 \\
$2-4$ & 22 & 16 \\
$4-6$ & 11 & 5 \\
$6-8$ & 5 & 2 \\
$8-16$ & 2 & - \\
\hline
\end{tabular}

Maximum D $=0.094$

Table VI shows the sulfonamides used for the maintenance treatment of group II.

T A B L E VI

Maintenance treatment of group II with sulfonamides

\begin{tabular}{|c|c|c|c|}
\hline $\begin{array}{l}\text { Drug } \\
\text { No. of cases } \\
\text { Dose (g) }\end{array}$ & $\begin{array}{l}\text { Sulfadimethoxin } \\
\text { (12) }\end{array}$ & $\begin{array}{c}\text { Sulfadoxin } \\
\text { (27) }\end{array}$ & $\begin{array}{l}\text { Sulfadimethoxin } \\
\text { and } \\
\text { Sulfadoxin } \\
\text { (6) }\end{array}$ \\
\hline Minimum & 30 & 8 & 68 \\
\hline Maximum & 1387 & 216 & 4800 \\
\hline Mean & 128.28 & 11.2 & 2100.75 \\
\hline
\end{tabular}

The statistical analyses for treatment comparison were based on the data in Table VII, which shows distribution by phase and class for the patients in both groups, except for pha. se 2 for which no comparison was possible because the data obtained were identical. 
DILlON, N. X.; SAMPAIO, S. A. P.; HABERMANN, M. C.; MARQUES, S. S.; LASTORIA, J. C.; STOLF, H. O.; SILVA, N.

C. de A. \& CURI, P. R. - Delayed results of treatment of paracoccidioidomycosis with amphotericin B plus sulfamides versus amphotericin B alone. Rev. Inst. Med. trop. Sāo Paulo, 28:263-266, 1986.

T A B L E VII

Retrospective therapeutic evaluation of the groups

\begin{tabular}{|c|c|c|c|c|c|c|c|c|c|c|}
\hline $\begin{array}{l}\text { Years without } \\
\text { treatment } \\
\text { Evaluation }\end{array}$ & $\begin{array}{l}\text { up to } \\
\text { Group } \mathrm{I}\end{array}$ & $\begin{array}{l}1 \text { year } \\
1 \\
\text { Group II }\end{array}$ & 1 to 2 & years & $\begin{array}{l}2 \text { to } 5 \\
\text { Group I }\end{array}$ & $\begin{array}{l}5 \text { years } \\
\text { Group II }\end{array}$ & 5 to & $\begin{array}{l}9 \text { years } \\
\mathrm{F}_{4} \\
\text { Group II }\end{array}$ & $\begin{array}{l}9 \text { to } 14 \\
\text { Group I }\end{array}$ & $\begin{array}{l}\text { years } \\
\text { Group II }\end{array}$ \\
\hline FCRS & 2 & 5 & 2 & 2 & 1 & 7 & 2 & 4 & 8 & 5 \\
\hline $\mathbf{S A}$ & 5 & 8 & 3 & 3 & 5 & 3 & 4 & 2 & 2 & - \\
\hline WCRS & 16 & 1 & 1 & 1 & 7 & - & 1 & - & 3 & - \\
\hline DWSL & 4 & 1 & - & - & 2 & - & - & - & 1 & - \\
\hline Total & 27 & 15 & 6 & 6 & 15 & 10 & 7 & 6 & 14 & 5 \\
\hline
\end{tabular}

FCRS = free from clinical, radiologic or serologic lesions. SA $=$ with serologic activity only

WCRS $=$ with clinical, radiologic and serologic lesions

DWSL $=$ death with spećific lesions

Difference between groups was observed in phases 1 and 2 owing to the concentration of patients submitted to treatment 2 in classes FCRS and SA. No significant difference in patient distribution was observed in phase 6 . However, if the same proportions of occurrence were maintained and the number of patients observed were increased, difference between treatments would also be obtained at the expense of treatment 2.

The indices obtained were always higher for treatment 2 at all phases (Table VIII), with an

T A B L E VIII

Group indices

\begin{tabular}{lcc}
\hline Phases & Group I & Group II \\
\hline F 1 & 2.6666 & 5.0000 \\
F 2 & 5.0000 & 5.0000 \\
F 3 & 2.9333 & 6.8000 \\
F 4 & 4.8571 & 6.6666 \\
F 5 & 5.6428 & 8.0000 \\
\hline
\end{tabular}

Binomial test, $\mathrm{p}=0.0625$

even greater difference starting from phase 3 (2 to 4 years). The statistical differences observed were due to the larger number of patients submitted to treatment 2 in classes WCRS and SA, which indicate better clinical conditions at all phases of follow-up, and were even more noticeable after 2 years of patients cured by treatment 2 is higher than cured by treatment 1.

Thus we conclude that the use of amphotericin $\mathrm{B}$ and maintenance treatment with sulfonamide derivatives of paracoccidioidomycosis is more effective than the use of amphotericin $B$ alone, even at high doses.

\section{RESUMO}

Resultados tardios do tratamento da paracoccidioidomicose com anfotericina $B$ mais sulfamídicos "versus" anfotericina B isoladamente

Os Autores avaliam tardiamente dois gru. pos de doentes de paracoccidioidomicose. Am. bos foram tratados com anfotericina $B$, tendo um deles feito tratamento de manutenção com sulfamídicos.

Através de análises estatísticas comprovam a maior eficácia do tratamento, quando se faz a manutenção com sulfamídicos.

\section{REFERENCES}

1. BARBOSA, W. \& DAHER, R. A. - Tratamento da blastomicose sul-americana com o RO 4-4393. Rev. goians Med., 12: 49-58, 1966.

2. BARBOSA, W. \& VASCONCELOS, W. M. de P. V. Ação da sulfametoxazol associada ao trimetoprim na terapêutica da blastomicose sul-americana. Rev. Pat. trop., 2: 329-339, 1973.

3. CASTRO, R. M. - Nefrotoxicidade da anfotericina $B$. Estudo em material de biópsia. São Paulo, 1965. (Tese de livre-docência - Faculdade de Medicina da Universìdade de São Paulo).

4. CASTRO, R. M.; BRITO, T.; PENNA, D. O.; FREY. MULLER, E. \& SAMPAIO, S. A. P. - Kidney lesions in amphotericin B therapy. An electron microscopy study (preliminary report). Rev. Inst. Med. trop. S. Paulo, 7: 41-46, 1965.

5. CONTI-DIAZ, I. A. \& CALEGARI, I. F. - Paracoceldioidomicosis en Uruguay: Su estado y problematica actuales. Bol. Ofic. sanit. panamer., 86: 219-229, 1979

6. DILLON, N. L. -.- Tratamento da paracoccidoidomicose pela anfotericina B. Avaliação de 119 doentes num pe ríodo de 14 anos. São Paulo, 1972. (Tese de doutora 
DILloN, N. L.; SAMPAIO, S. A. R.; HABERMANN, M. C.; MARQUES, S. S.; LASTORIA, J. C.; STOLF, H. O.; SILVA, N. C. de A. \& CURI, P. R. - Delayed results of treatment of paracoccidioidomycosis with amphotericin B plus sulfa. mides versus amphotericin B alone. Rev. Inst. Med. trop. Săo Paulo, 28:263-266, 1986.

mento - Faculdade de Medicina da Universidade de São Paulo).

7 hUTZLER, R. V.; AMATO NETO, V; FAVA NETTO, C. \& LEAO, V. S. C. - Tratamento da blastomicose sul-americana com um sulfamidico de eliminação urinária lenta e administração semanal. Hospital (Rio de J.), 66: 91.97, 1964 .

8. LACAZ, C. da S. \& SAMPAIO, S. A. P. - Tratamento da blastomicose sul-americana com anfoterictna B. Resultados prelininares. Rev. paul. Med., 5Z: 443-450, 1958.

9. LOPES, C. F. - Evaluación de los resultados obtenidos en el tratamiento de la blastomicosis sudamericana con sulfamida de administración semanal. Med. cut., 5: 357-366, 1971.

10. MACHADO FILHO, J. \& MIRANDA, J. L. - Sobre a açăo da sulfametoxipiradazina na blastomícose sulamericana. Rev. bras. Med, 16: 168-170, 1959.

11. NOHMI, N. - Doença de Lutz tratada pela sulfametoxipiridazina. Hospital (Rlo de J.), 63: 783-790, 1963.
12. PADILHA-GONÇALVES, A. - Tratamento da blastomicose sul-americana pela sulfametoxipiridazina. Hospital (Rio de J.), 56: 747-750, 1959.

13. SAMPaIO, S. A. P. - Tratamento da blastomicose sul-americana com anfotericina B. Săo Paulo, 1960. (Tese de cátedra - Faculdade do Medicina da Universidade de São Paulo).

14. TRANCHESI, J.; CAMPANA, C. L. \& SAMPAIO, S. A. P. - Alteraçöes eletrocardiográficas observadas durante - tratamento da blastomicose pela anfotericina B. (Nota preliminar). Rev. Hosp. Clín. Fac. Med. S. Paulo, 15: 126-130, 1960.

15. RIBEIRO, D. O. - Nova terapeutica para a blasto. micose. Puhl. méd., (S. Paulo(, 12: 36-54, 1940.

16. SIEGEL, S. - Estatísticas não paramétricas. Săo Paulo. Mc Graw Hill do Brasil, 1975. p. 350.

Recebido para publicaçăo em 5/8/1985 